\title{
On the Contribution of the First Transmembrane Domain to Whole- Cell Current through an ATP-Gated Ionotropic P2X Receptor
}

\author{
William R. Haines, Mark M. Voigt, Keisuke Migita, Gonzalo E. Torres, and Terrance M. Egan \\ Department of Pharmacological and Physiological Science, St. Louis University School of Medicine, St. Louis, Missouri \\ 63104
}

\begin{abstract}
Scanning cysteine mutagenesis was used to identify potential pore-forming residues in and around the first transmembrane domains of ionotropic $\mathrm{P}_{2} \mathrm{X}_{2}$ receptor subunits. Twenty-eight unique cysteine-substituted mutants (R28C-Y55C) were individually expressed in HEK293 cells by lipofection. Twenty-three of these were functional as assayed by application of ATP to transfected voltage-clamped cells. Individual mutants varied in their sensitivity to ATP; otherwise, currents through functional mutant receptors resembled those of the homomeric wild-type (WT) receptor. In five (H33C, R34C, I50C, K53C, and S54C) of 23 functional mutants, coapplication of $30 \mu \mathrm{M}$ ATP and $500 \mathrm{~nm}$ $\mathrm{Ag}^{+}$irreversibly inhibited inward current evoked by subsequent
\end{abstract}

applications of ATP alone. These inhibitions did not result in a lateral shift in the agonist concentration-response curve and are unlikely to involve a modification of the agonist binding site. Two (K53C and S54C) of the five residues modified by $\mathrm{Ag}^{+}$ applied in the presence of ATP when the channels were gating were also modified by $1 \mathrm{~mm}$ (2-aminoethyl)methanethiosulfonate applied in the absence of ATP when the channels were closed. These data suggest that domains near either end of the first transmembrane domain influence ion conduction through the pore of the $\mathrm{P} 2 \mathrm{X}_{2}$ receptor.

Key words: ATP; scanning cysteine mutagenesis; purinergic; ion channel; ligand-gated; methanethiosulfonate
ATP is unusual in its ability to influence cell activity from both the intracellular and extracellular compartments. Intracellular hydrolysis of ATP to adenosine $5^{\prime}$-diphosphate and inorganic phosphate provides the energy needed to drive a wide range of energetically unfavorable chemical reactions and is an important source of phosphate in many biosynthetic reactions (Alberts et al., 1998). Extracellular ATP modulates cell excitability by activating membrane-bound P2 purinoceptors (Ralevic and Burnstock, 1998). One branch of this family, the P2X receptors, is a class of ligand-gated ion channels that conduct the flow of cations across the cell surface membranes of a wide variety of tissues (Khakh et al., 2001). Conduction occurs when the ion channel opens as a result of agonist occupation of an extracellular binding site. The molecular mechanism by which occupation evokes channel gating remains a mystery, attributable in part to an incomplete mapping of the functional domains of the receptor complex, including the agonist binding site and the channel pore. The general location of the ion-conducting pore can be inferred from recent experiments that examined the secondary structure of individual isoforms. P2X receptors incorporate at least three equivalent subunits (Kim et al., 1997; Nicke et al., 1998) and are homomeric or heteromeric in composition (Torres et al., 1999). Each subunit within a complex crosses the membrane twice in such a way that the intracellular $\mathrm{N}$ and $\mathrm{C}$ termini are linked by a large ectodomain (Torres et al., 1998), and one or both of the short intramembra-

Received March 13, 2001; revised May 15, 2001; accepted May 30, 2001.

This work was supported by National Institutes of Health Grants HL56236 and NS35534 and an American Heart Association-Missouri Affiliate predoctoral fellowship (W.R.H.). T.M.E. is an Established Investigator of the American Heart Association. We thank Laura Hobart for help with tissue culture and transfections, and Drs. A. Brake and D. Julius for cDNA encoding the $\mathrm{P}_{2} \mathrm{X}_{2}$ receptor subunit.

Correspondence should be addressed to Dr. Terrance M. Egan, Department of Pharmacological and Physiological Science, St. Louis University School of Medicine, 1402 South Grand Boulevard, St. Louis, MO 63104. E-mail: egantm@slu.edu. Copyright (C) 2001 Society for Neuroscience $0270-6474 / 01 / 215885-08 \$ 15.00 / 0$ neous domains probably line the ion-conducting pore. At least part of the pore wall comes from the second transmembrane domain (TMD2) that runs from approximately I331 to L353. This is implied from studies that show that hydrophilic sulfhydrylspecific ligands modify currents through some but not all cysteine-substituted mutants of TMD2 of $\mathrm{P} 2 \mathrm{X}_{2}$ receptors (Rassendren et al., 1997; Egan et al., 1998). Furthermore, point mutations of some polar residues within TMD2 of homomeric $\mathrm{P} 2 \mathrm{X}_{2}$ receptors alter monovalent cation and $\mathrm{Ca}^{2+}$ permeability in a manner consistent with an effect on the ion selectivity filter of the channel pore (Migita et al., 2001). However, the fact that TMD2 lines the pore does not rule out a contribution from the other putative intramembraneous region, and the role of the first transmembrane domain (TMD1) has not been studied. In the present study, we investigated the role of TMD1 in ion conduction using the same techniques we used previously to probe TMD2 (Egan et al., 1998). We made 28 unique cysteine-substituted mutations in or around TMD1 of the $\mathrm{P}_{2} \mathrm{X}_{2}$ isoform. ATP-gated currents through wild-type (WT) and mutant $\mathrm{P}_{2} \mathrm{X}_{2}$ receptors transiently expressed in human embryonic kidney-293 (HEK293) cells were measured under voltage-clamp before and after covalent modification by $500 \mathrm{nM} \mathrm{Ag}^{+}$or $1 \mathrm{~mm}$ (2-aminoethyl)methanethiosulfonate (MTSEA). $\mathrm{Ag}^{+}$and/or MTSEA irreversibly inhibited current through five mutants. The data suggest that TMD1 makes a measurable contribution to ion conduction through the $\mathrm{P} 2 \mathrm{X}_{2}$ receptor and may form part of the wall of the pore.

\section{MATERIALS AND METHODS}

The methods used in this study were described in detail previously (Egan et al., 1998); a concise description is presented here. The $\mathrm{P} 2 \mathrm{X}_{2}$ isoform was chosen as the experimental model because it shows less desensitization than other family members.

Preparation and handling of cDNAs. Site-directed mutagenesis of the $\mathrm{P} 2 \mathrm{X}_{2}$ receptor was performed using the overlap-primer extension method (Ausubel et al., 1995). Mutations were verified by sequencing using the de-azaGTP Sequenase kit from Amersham Pharmacia Biotech. 
HEK293 cells were transfected by lipofection using $1 \mu \mathrm{g}$ of cDNA and 6 $\mu l$ of LipoFectamine (Life Technologies, Gaithersburg, MD) per $3.0 \times$ $10^{5}$ cells plated on $35 \mathrm{~mm}$ culture dishes. Transfected cells were incubated in a humidified atmosphere containing $5 \% \mathrm{CO}_{2}$ at $37^{\circ} \mathrm{C}$ for $24-48$ $\mathrm{hr}$ before electrophysiological analysis. Transfection efficiency varied among the WT and mutant receptors, although it typically was not difficult to find cells that expressed robust currents in response to short applications of ATP.

Electrophysiology. Single HEK293 cells were obtained by mechanical dispersion of a population of cells obtained from a single culture dish. Whole-cell current was recorded using AxoPatch 200 series amplifiers (Axon Instruments, Foster City, CA) and low-resistance electrodes (1-2 $\mathrm{M} \Omega)$. The holding voltage $\left(V_{\mathrm{h}}\right)$ was $-40 \mathrm{mV}$ in most experiments, although a smaller driving force $\left(-40>V_{\mathrm{h}} \geq-20 \mathrm{mV}\right)$ was used in a few experiments to keep the current amplitude within the limits of the recording apparatus. We saw no obvious differences in the ability of $\mathrm{Ag}^{+}$ or MTSEA to modify cysteine-substituted mutant $\mathrm{P} 2 \mathrm{X}_{2}$ receptors in a voltage-dependent manner in this limited range of membrane voltage. Recording pipettes were filled with the following intracellular solution (in $\mathrm{mM}$ ): $150 \mathrm{CsCl}, 10$ tetraethylammonium-Cl, 10 EGTA, and 10 HEPES, pH 7.3 with $\mathrm{CsOH}$. When $\mathrm{Ag}^{+}$was used, a salt-agar bridge to ground was used to minimize junctional offsets, and the extracellular solution was (in mM): $150 \mathrm{NaNO}_{3}, 1 \mathrm{Ca}\left(\mathrm{NO}_{3}\right)_{2}, 1 \mathrm{Mg}\left(\mathrm{NO}_{3}\right)_{2}, 10$ glucose, and 10 HEPES, pH 7.3 with $\mathrm{NaOH}$. When MTSEA was used, the extracellular solution was (in mM): $150 \mathrm{NaCl}, 1 \mathrm{CaCl}_{2}, 1 \mathrm{MgCl}_{2}, 10$ glucose, and 20 HEPES, pH 7.0 with $\mathrm{NaOH}$; this relatively low $\mathrm{pH}$ was used to slow hydrolysis of MTSEA (Karlin and Akabas, 1998) (see also Egan et al., 1998). Drugs were applied by manually moving the electrode and attached cell into the line of flow of solutions exiting one of an array of inlet tubes. Each application lasted $\sim 3 \mathrm{sec}$, and successive applications were separated by at least $2 \mathrm{~min}$ to minimize receptor desensitization. MTSEA was purchased from Toronto Research Chemicals Inc. (Toronto, Canada). All other reagents were purchased from Sigma (St. Louis, MO).

Data analysis. The effects of $\mathrm{Ag}^{+}$and MTSEA on current amplitudes were plotted as percentage of change from control measured from the averages of an equal number (three or more) of steady-state responses obtained before $\left(I_{\mathrm{ATP}, \text { before }}\right)$ and after $\left(I_{\mathrm{ATP}, \text { after }}\right)$ application of a modifying reagent to a single cell. Percentage of change was calculated as the following: $\%$ change $=\left[\left(I_{\mathrm{ATP}, \text { after }} / I_{\mathrm{ATP}, \text { before }}-1\right) \times 100\right]$.

Each experiment was repeated three to nine times, and the results are displayed as the mean \pm SEM for the number of experiments indicated. Differences between groups were determined by one-way ANOVA, and significance levels were calculated with the Tukey-Kramer post hoc test using StatView 5.0 (SAS Institute, Cary, NC). Values of $p=0.01$ were considered to be statistically significant.

Concentration-response curves were generated by measuring the currents evoked by a range of concentrations of ATP in single cells. These currents were then normalized to those evoked by $100 \mu \mathrm{M}$ ATP in the same cell, and the data were fit using the Hill equation algorithm of IgorPro 4.0 (WaveMetrics Inc., Lake Oswego, OR) to determine the $\mathrm{EC}_{50}$ of ATP. The currents evoked after $\mathrm{Ag}^{+}$modification were normalized to the effect of $100 \mu \mathrm{M}$ ATP applied after modification had occurred. The $\mathrm{EC}_{50}$ values from individual experiments were grouped according to mutation and drug treatment from which the mean \pm SEM for each group $(n=3-11)$ was determined. Statistical significance $(p=0.01)$ was estimated using Student's $t$ test.

\section{RESULTS}

Hydrophobicity plots predict that each subunit of a multimeric $\mathrm{P} 2 \mathrm{X}_{2}$ receptor complex crosses the membrane twice (Brake and Julius, 1996), and this hypothesis is supported by empirical data (Torres et al., 1998). In a previous report, we used scanning cysteine mutagenesis to demonstrate that TMD2 lines a part of the channel pore (Egan et al., 1998). In the present report, we applied this technique to TMD1 to determine whether this domain plays a role in ion conduction. TMD1 is thought to traverse the membrane from approximately F31 to V51 (Newbolt et al., 1998). Twenty-eight different $\mathrm{P} 2 \mathrm{X}_{2}$ receptor mutants (designated R28C, L29C, ..., Y55C) were constructed in such a way that each mutant had a single cysteine substitution at a different position in or around TMD1 (Fig. 1). These mutant receptors were transiently expressed in HEK293 cells and studied under voltage

\section{RRLGFVHRMVQLLILLYFVWYVF IVQKSYQ $\mathrm{CCCCCCCCCCCCCCCCCCCCCCCCCCCC}$ ** $\star$ $\star \star \star$}

Figure 1. Placement of cysteine substitutions in and around the stretch of amino acids thought to traverse the membrane as TMD1. Amino acid alignment is indicated using single letter codes for individual amino acids of the wild-type $\mathrm{P} 2 \mathrm{X}_{2}$ receptor. Each native residue mutated to cysteine is marked beneath the changed amino acid with a $C$. Cysteine substitutions at amino acids marked with asterisks failed to respond to applications of up to $1 \mathrm{mM}$ ATP. The absolute limits of the TMD1 of P2X $\mathrm{X}_{2}$ are unknown; the solid line indicates its approximate location based on hydropathy plots of primary structure (Brake et al., 1994) and glycosylation scanning mutagenesis (Newbolt et al., 1998).

clamp at a membrane potential (usually $-40 \mathrm{mV}$ ) at which ATP $(30 \mu \mathrm{M})$ was expected to evoke inward currents if the mutant receptors resembled the WT receptor in their nonselective permeability to cations. Five (R28C, L29C, Y43C, Q52C, and Y55C) of the 28 mutant receptors failed to respond to ATP, even when this agonist was applied at a concentration $(1 \mathrm{~mm})>60$ times larger than its $\mathrm{EC}_{50}(16 \pm 3 ; n=11)$ at the $\mathrm{WT}$ receptor. The remaining 23 mutants were functional and responded to ATP with inward currents that resembled the WT receptor in rate of onset, offset, desensitization, and resensitization. The accessibilities of the functional cysteine-substituted receptors were then tested using $\mathrm{Ag}^{+}$to probe gating channels and MTSEA to probe closed channels.

Application of scanning cysteine mutagenesis to the identification of pore-lining residues is based on certain assumptions (Karlin and Akabas, 1998). We assume the following: (1) the ion channel pore is formed in part by the transmembrane domains; (2) engineered cysteine substitutions within these domains do not lead to dramatic changes in channel structure; (3) thio-reactive reagents (such as $\mathrm{Ag}^{+}$and MTSEA) react more readily with the ionized -S- of a hydrated cysteine projecting into the pore than with the unionized - $\mathrm{SH}$ of cysteines projecting into the lipid membrane; and (4) modification of some hydrated cysteine side chains projecting into the pore cause an irreversible change in current flow through the channel.

\section{The effect of $\mathrm{Ag}^{+}$on gating channels}

The effect of a short $(5 \mathrm{sec})$ coapplication of $500 \mathrm{nM} \mathrm{Ag}^{+}$and 30 $\mu \mathrm{M}$ ATP on subsequent applications of ATP alone was measured to determine the effect of $\mathrm{Ag}^{+}$on both the open and closed states of the channel. $\mathrm{Ag}^{+}$resembles $\mathrm{K}^{+}$in atomic radius and dehydration energy and might be expected to interact with hydrated residues of the $\mathrm{P} 2 \mathrm{X}_{2}$ receptor in a manner approximating that of the physiologically relevant monovalent cations. In addition, $\mathrm{Ag}^{+}$ reacts in a strong and irreversible manner with thiolates to form a stable S-Ag bond (Dance, 1986); this reaction has been shown to alter current through ion channels if it occurs at a cysteine lining the channel pore (Lü and Miller, 1995; Sun et al., 1996; Egan et al., 1998; Kriegler et al., 1999). We applied ATP once every 3 min until a stable baseline response was established. Then, $500 \mathrm{~nm} \mathrm{Ag}^{+}$was coapplied with ATP for $5 \mathrm{sec}$, after which ATP was again applied alone at 3 min intervals to reestablish a stable current response. Average peak current amplitudes were compared before and after modification to determine accessibility.

As reported previously, a short (less than $\sim 10 \mathrm{sec}$ ) coadministration of $\mathrm{Ag}^{+}$and ATP had no sustained effect on the WT 

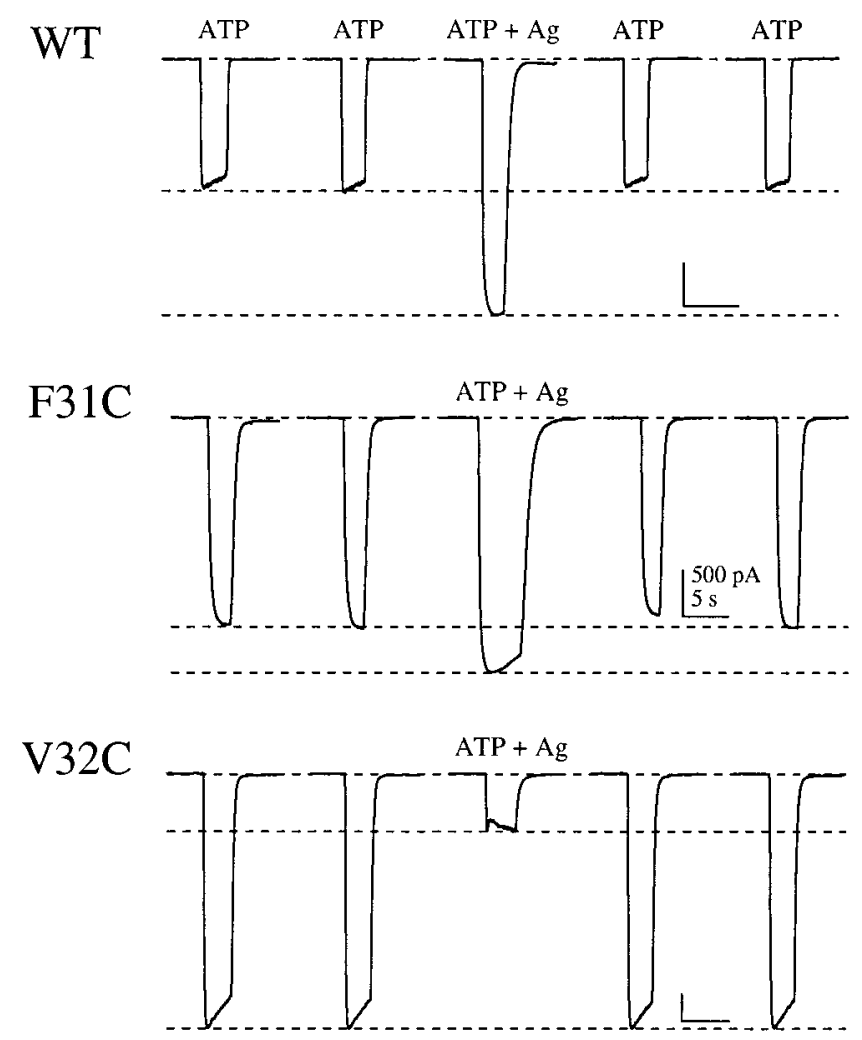

Figure 2. Transient effects of coapplications of $\mathrm{Ag}^{+}$and ATP. Each row shows inward currents evoked by $30 \mu \mathrm{M}$ ATP before (2 leftmost traces of each row), during (middle trace of each row), and after (2 rightmost traces of each row) application of $500 \mathrm{~nm} \mathrm{Ag}^{+}$. Both WT (top) and F31C (middle) receptors are transiently potentiated by coapplications of ATP and $\mathrm{Ag}^{+}$. Of 58 cysteine-substituted mutants of TMD1 (this paper) and TMD2 (Egan et al., 1998), only V32C (bottom) was transiently inhibited by $\mathrm{Ag}^{+}$. Holding voltage was $-40 \mathrm{mV}$. Calibration: $500 \mathrm{pA}, 10 \mathrm{sec}$.

receptor. Although $\mathrm{Ag}^{+}$did cause a transient potentiation of ATP-gated current that reversed immediately upon washout, subsequent ATP applications evoked currents whose averaged amplitude was not significantly different from that of control (Fig. 2, top). Longer (greater than $\sim 10 \mathrm{sec}$ ) applications of $\mathrm{Ag}^{+}$weakened the seal between the glass electrode and the cell membrane (Egan et al., 1998) and were therefore avoided in the present study.

Coapplication of $\mathrm{Ag}^{+}$and ATP had one of four effects on functional mutant receptors. First, $\mathrm{Ag}^{+}$transiently potentiated ATP-gated current through 17 of 23 mutants but did not significantly alter currents evoked by subsequent applications of ATP alone (Fig. 2, middle). These transient potentiations resembled those of the WT receptor. Second, $\mathrm{Ag}^{+}$transiently inhibited ATP-gated current through the $\mathrm{V} 32 \mathrm{C}$ receptor in a reversible manner (Fig. 2, bottom). The mechanism of this transient inhibition is unknown. Third, $\mathrm{Ag}^{+}$caused an immediate and irreversible inhibition of four mutants (R34C, I50C, K53C, and S54C). These inhibitions occurred soon after the start of application of $\mathrm{Ag}^{+}$and were seen as a progressive decrease in current amplitude during the $5 \mathrm{sec}$ coadministrations of $\mathrm{Ag}^{+}$and ATP (Fig. 3). Subsequent applications of ATP evoked stable currents that were significantly smaller than their premodification controls, and, in all cases, these inhibitions did not reverse during the lifetime of the giga seal between the recording electrode and the cell membrane. Fourth, $\mathrm{Ag}^{+}$caused an irreversible inhibition of ATP-
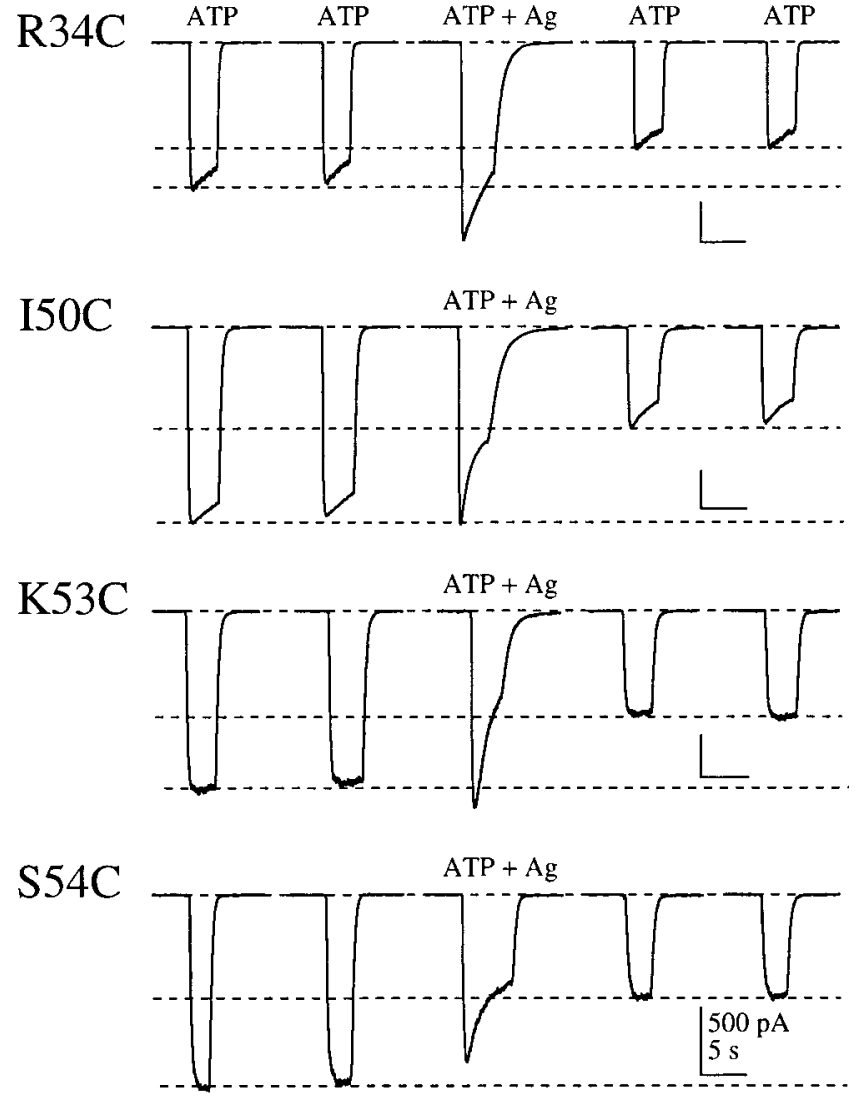

Figure 3. Irreversible effects of $\mathrm{Ag}^{+}$on R34C, I50C, K53C, and S54C. $\mathrm{Ag}^{+}(500 \mathrm{nM})$ was coapplied with $30 \mu \mathrm{M}$ ATP to modify gating channels. Each row shows two consecutive and representative ATP-gated currents before (2 leftmost traces in each row) and after (2 rightmost traces in each row) a $5 \mathrm{sec}$ coapplication of $\mathrm{Ag}^{+}$and ATP (middle trace in each row) using HEK293 cells transiently expressing the indicated cysteinesubstituted mutant $\mathrm{P} 2 \mathrm{X}_{2}$ receptor. In the absence of $\mathrm{Ag}^{+}$, ATP was applied for $3 \mathrm{sec}$, and successive applications were separated by $3 \mathrm{~min}$. Holding voltage was $-40 \mathrm{mV}$. Calibration: $500 \mathrm{pA}, 5 \mathrm{sec}$.

gated current through $\mathrm{H} 33 \mathrm{C}$ receptors that was preceded by a long-lasting potentiation. Like the WT receptor, coapplication of $\mathrm{Ag}^{+}$and ATP resulted in a larger inward current than did application of ATP alone (Fig. 4a). However, unlike the effect on WT or any other mutant receptor (Egan et al., 1998), the potentiation of ATP-gated current outlasted the $\mathrm{Ag}^{+}$application by several minutes (Fig. 4b). Typically, the first post- $\mathrm{Ag}^{+}$application of ATP alone was larger than control but slightly smaller than that evoked by the preceding concurrent administration of both drugs. Subsequent applications of ATP continued to evoke supranormal currents for tens of minutes, often outlasting the life span of the giga seal, although the size of the current became progressively smaller with each pulse of ATP. The amplitude of the ATP-gated current eventually became significantly smaller than the pre- $\mathrm{Ag}^{+}$application controls, resolving to an steady-state current that was on average $\sim 40 \%$ smaller than that of the control response. A second coapplication of $\mathrm{Ag}^{+}$and ATP neither transiently potentiated nor further inhibited ATP-gated current (data not shown), indicating that the first application of $\mathrm{Ag}^{+}$had produced a near complete covalent modification of the accessible residue. A summary of the sustained effects of $\mathrm{Ag}^{+}$on all functional TMD1 mutants is presented in Figure 5. 

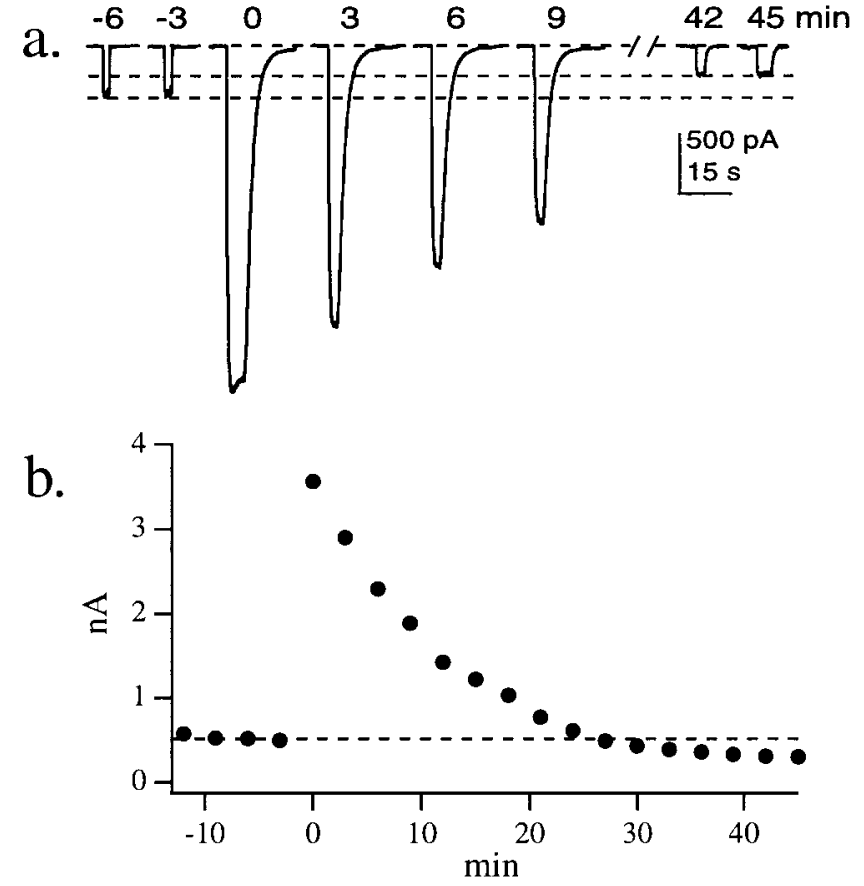

Figure 4. Nature and time course of the effect of $\mathrm{Ag}^{+}$on H33C. $a$, ATP $(30 \mu \mathrm{M})$ was applied once every 3 min to an HEK293 cell expressing the H33C mutant. The two leftmost currents $(t=-6$ and $-3 \mathrm{~min})$ are examples of the premodification controls. $\mathrm{Ag}^{+}(500 \mathrm{nM})$ and ATP were coapplied at $t=0$, resulting in a marked potentiation of ATP-gated current that outlasted the $\mathrm{Ag}^{+}$application. The potentiation of current eventually resolved to a sustained inhibition of current (2 rightmost currents; 42 and $45 \mathrm{~min}$ ). $b$, The time course of change in peak current amplitude for the cell shown above. Holding voltage was $-40 \mathrm{mV}$.

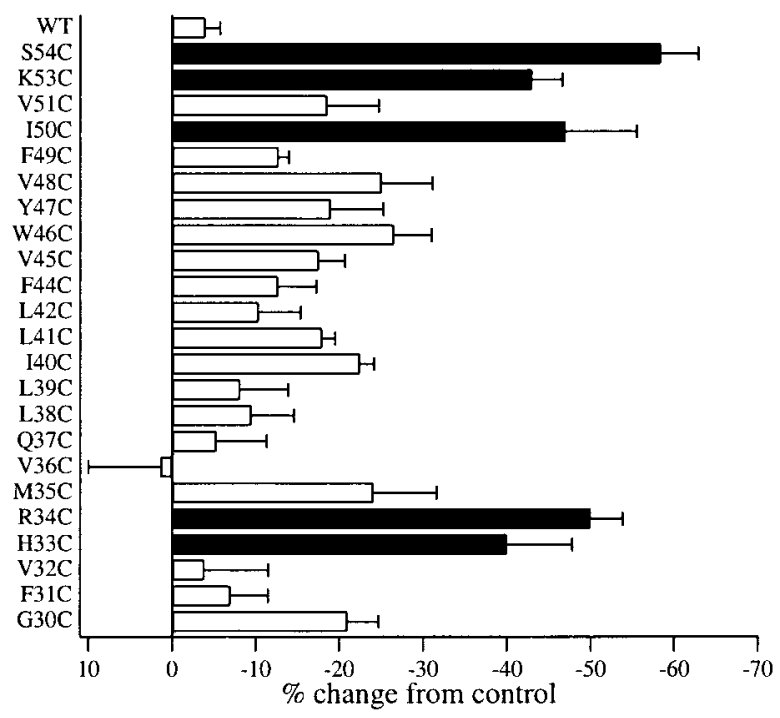

Figure 5. Averaged data for the sustained effects of $\mathrm{Ag}^{+}$on wild-type $\mathrm{P}_{2} \mathrm{X}_{2}$ and 23 functional cysteine-substituted TMD1 mutants. Data for wild-type and each mutant are the average of three to nine individual experiments. Results significantly different $(p<0.01)$ from WT are marked with solid bars. Error bars equal the SEM.

\section{The effects of $\mathrm{Ag}^{+}$on agonist potency}

A tenet of the scanning cysteine mutagenesis method is that sulfhydryl modifications that alter current amplitudes indicate an effect on a pore-forming residue (Karlin and Akabas, 1998). This is difficult to prove empirically using a functional assay, and other explanations are possible. For example, modification of part of a signal transduction pathway that links the ligand binding site to the channel gate may shift the agonist concentration-response curve to the right, causing submaximal concentrations of agonist to evoke smaller currents after modification than before (Jiang et al., 2000). To determine whether shifts in agonist potency caused the changes in current amplitudes observed for the five reactive mutants, we constructed ATP concentration-response curves before and after application of $\mathrm{Ag}^{+}$for the five mutants shown to be susceptible to modification. Two results are worth noting. First, three (H33C, R34C, and K53C) of the five unmodified cysteinesubstituted TMD1 mutants were significantly less sensitive to ATP than was the WT receptor (Fig. $6 a$, Table 1). The average $\mathrm{EC}_{50}$ values measured before applications of $\mathrm{Ag}^{+}$were as follows: $\mathrm{WT}, 16 \pm 3 \mu \mathrm{M}$; H33C, $59 \pm 8 \mu \mathrm{M}$; R34C, $30 \pm 2 \mu \mathrm{M}$; I50C, $22 \pm$ $4 \mu \mathrm{M}$; K53C, $52 \pm 3 \mu \mathrm{M}$; and S54C, $19 \pm 4 \mu \mathrm{M}$. Although the mechanism(s) of the changes in potencies is unknown, the fact that mutations in or very near TMD1 change agonist potency suggests that this domain plays an active role in gating or transduction. Second, $\mathrm{Ag}^{+}$irreversibly inhibited peak current through the five accessible mutant receptors at all concentrations of ATP tested, and the inhibitions at the highest ATP concentrations were not overcome by increasing concentrations of ATP. Furthermore, there was no statistically significant difference (even when estimated at $p<0.05$ ) in the potency of ATP before and after modification by $\mathrm{Ag}^{+}$for any of the susceptible mutants (Fig. $6 b-f)$. The normalized data of R34C, I50C, K53C, and S54C are relatively straightforward, and the lack of significant shifts in the concentration-response curves of these mutants after $\mathrm{Ag}^{+}$modification are clear in the graphs of Figure $6 c-f$. The $\mathrm{EC}_{50}$ values determined after application by $\mathrm{Ag}^{+}$were as follows: R34C, $28 \pm$ $5 \mu \mathrm{M}$; I50C, $34 \pm 8 \mu \mathrm{M}$; K53C, $44 \pm 3 \mu \mathrm{M}$; and S54C, $24 \pm 7 \mu \mathrm{M}$. These data demonstrate that a change in agonist potency does not underlie the decrease in current amplitude caused by $\mathrm{Ag}^{+}$modification of these four mutants.

The steady-state attenuation of $\mathrm{H} 33 \mathrm{C}$ was preceded by a longlasting potentiation that made quantification of these data more problematic (Fig. 4). To determine how $\mathrm{Ag}^{+}$augmented current, concentration-response curves were also generated during the potentiation phase. As shown in Figure $6 b, \mathrm{Ag}^{+}$caused a shift to the left in the ATP concentration-response curve for $\mathrm{H} 33 \mathrm{C}$ during potentiation. The $\mathrm{EC}_{50}(5 \pm 1 \mu \mathrm{M})$ for ATP measured at this time was significantly different $(p<0.01)$ than that of the premodified control. Although this $\mathrm{EC}_{50}$ should be considered an estimate of the actual potency of ATP because the steady decline of current during potentiation introduced an error into the construction of concentration-response curves, the data nonetheless suggest that an early effect on signal transduction had occurred. In contrast, the $\mathrm{EC}_{50}(45 \pm 10 \mu \mathrm{M})$ measured during the late steady-state inhibition of $\mathrm{H} 33 \mathrm{C}$ was not different from the unmodified control, even when tested at $p<0.05$, indicating that a change in agonist potency does not underlie the persistent inhibition by $\mathrm{Ag}^{+}$. Together, the data suggest that $\mathrm{H} 33 \mathrm{C}$ plays an important role in $\mathrm{P} 2 \mathrm{X}_{2}$ channel function as a pore forming residue, a component of the transduction system that links receptor occupation to channel gating, or both.

\section{The effect of MTSEA on closed channels}

Some residues accessible during gating may also be accessible when the channel is closed. To test this hypothesis, we incubated cells expressing one of the five $\mathrm{Ag}^{+}$-accessible mutants in $1 \mathrm{~mm}$ 

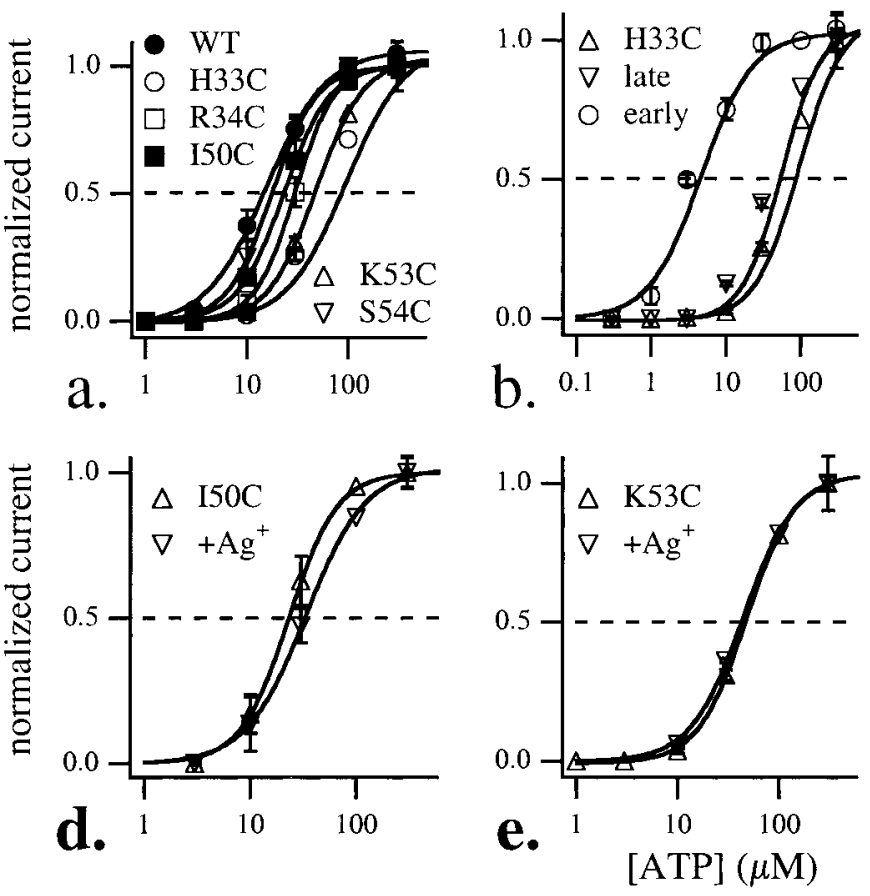

Table 1. The $\mathrm{EC}_{50}$ values and $n_{\mathrm{H}}$ values for unmodified and modified cysteine-substituted mutants

\begin{tabular}{lllr} 
Clone & $\mathrm{EC}_{50}(\mu \mathrm{M})$ & $n_{\mathrm{H}}$ & $n$ \\
\hline $\mathrm{WT}$ & $16 \pm 3$ & $1.5 \pm 0.1$ & 11 \\
$\mathrm{H} 33 \mathrm{C}$ & $59 \pm 8$ & $1.6 \pm 0.1$ & 6 \\
$\mathrm{H} 33 \mathrm{C}-\mathrm{Ag}^{+}$ & & & \\
$\quad$ early & $5 \pm 1$ & $1.4 \pm 0.3$ & 7 \\
$\mathrm{H} 33 \mathrm{C}-\mathrm{Ag}^{+}$late & $45 \pm 10$ & $1.5 \pm 0.1$ & 3 \\
R34C & $30 \pm 2$ & $2.2 \pm 0.1$ & 6 \\
R34C-Ag & $28 \pm 5$ & $1.5 \pm 0.3$ & 6 \\
I50C & $22 \pm 4$ & $2.0 \pm 0.1$ & 5 \\
I50C-Ag & $34 \pm 8$ & $1.5 \pm 0.1$ & 4 \\
K53C & $52 \pm 3$ & $1.8 \pm 0.1$ & 5 \\
K53C- $-\mathrm{Ag}^{+}$ & $44 \pm 3$ & $1.7 \pm 0.1$ & 4 \\
S54C & $19 \pm 4$ & $1.5 \pm 0.3$ & 3 \\
S54C-Ag & $24 \pm 7$ & $2.0 \pm 0.6$ & 3
\end{tabular}

The $\mathrm{EC}_{50}$ and $n_{\mathrm{H}}$ values from individual experiments were grouped according to mutation and drug treatment from which the mean \pm SEM for each group was determined. WT, H33C, R34C, I50C, K53C, and S54C indicate the unmodified receptor. Modified residues are suffixed with $-\mathrm{Ag}^{+} . \mathrm{H} 33 \mathrm{C}-\mathrm{Ag}^{+}$early, The modified $\mathrm{H} 33 \mathrm{C}$ receptor measured during the potentiation phase of the effect of $\mathrm{Ag}^{+}$; the $\mathrm{EC}_{50}$ of this receptor is an estimate of the true $\mathrm{EC}_{50}$ (see Results). $\mathrm{H} 33 \mathrm{C}-\mathrm{Ag}^{+}$late, The modified receptor measured during the late steady-state inhibition. Data are given as the mean $\pm \mathrm{SEM}$ of the individual measurements determined in single cells.

MTSEA for $5 \mathrm{~min}$ between applications of ATP. MTSEA readily crosses cell lipid membranes because both the protonated and deprotonated forms of MTSEA are present at neutral $\mathrm{pH}$ and can modify residues on both sides of the membrane, even when the channel is closed (Holmgren et al., 1996; Karlin and Akabas, 1998). The protonated MTSEA reacts with cysteine by forming a disulfide bond that attaches $-\mathrm{SC}_{2} \mathrm{CH}_{2} \mathrm{NH}_{4}{ }^{+}$to thiolates exposed to water (Jakes et al., 1990; Akabas et al., 1992).

Long (5 min) applications of $1 \mathrm{~mm}$ MTSEA had no transient or irreversible effects on the ATP-gated currents of the WT receptor using the protocols deployed in these experiments (Egan et al.,

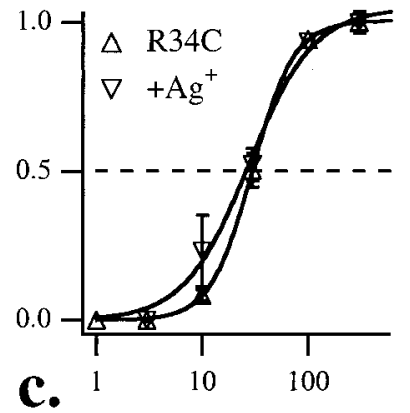

Figure 6. Concentration-response curves for ATP-gated current before and after $\mathrm{Ag}^{+}$modification. $a$, ATP concentration-response curves for wild-type and five cysteine-substituted $\mathrm{P} 2 \mathrm{X}_{2}$ receptor mutants. Control currents are normalized to those evoked by $100 \mu \mathrm{M}$ ATP in the same cell. Currents evoked after $\mathrm{Ag}^{+}$modification were normalized to the effect of $100 \mu \mathrm{M}$ ATP applied after modification had occurred. Symbols are averaged data for each concentration of applied ATP. Solid lines are the best fit of the averaged data to the Hill equation. The dotted line indicates the level of the half-maximal response. $b$, ATP concentration-response curves for $\mathrm{H} 33 \mathrm{C}$ were generated before $(\triangle)$ and after $(\bigcirc, \nabla)$ modification by $500 \mathrm{~nm} \mathrm{Ag}^{+}$. ATP-gated currents were measured during both the early potentiation $(O)$ and late inhibition $(\nabla)$ phases of the effects of $\mathrm{Ag}^{+}$on this mutant. $c-f$, ATP concentration-response curves generated before $(\triangle)$ and after $(\nabla)$ modification of R34C $(c), \mathrm{I} 50 \mathrm{C}(d), \mathrm{K} 53 \mathrm{C}$ $(e)$, and $\mathrm{S} 54 \mathrm{C}(f)$ by $500 \mathrm{~nm} \mathrm{Ag}^{+}$.

1998). Of the five mutants that were modified by $\mathrm{Ag}^{+}$coapplied with ATP, only K53C (Fig. 7a) and S54C (Fig. 7b) were significantly inhibited by MTSEA applied in the absence of ATP. These inhibitions were large, apparent during the first post-MTSEA application of ATP, and did not reverse over the time course of the remainder of the recording (up to $\sim 30 \mathrm{~min}$ ). It is particularly interesting to note that the average inhibition of S54C ( $80 \pm 5 \%$; $n=4)$ by MTSEA was far larger than that seen on any other TMD1 (Fig. 7c) or TMD2 cysteine-substituted mutant (Egan et al., 1998). The fact that some but not all of the residues modified by $\mathrm{Ag}^{+}$were also modified by MTSEA suggests that either the pattern of accessibility changes when the channel opens or $\mathrm{Ag}^{+}$ experiences less steric hindrance than MTSEA because it is smaller. It should be possible to distinguish between these possibilities if a single modifying reagent could be applied both when the channels are gating (e.g., in the presence of ATP) and when these channels are always closed (e.g., in the absence of ATP). This experiment was not possible using the methods described here because of the following: (1) longer applications of $\mathrm{Ag}^{+}$ were necessary to probe accessibility of closed channels, and these long ( $\geq 10 \mathrm{sec}$ ) applications activated nonspecific currents; and (2) coapplication of MTSEA and ATP to gating channels lead to nonspecific effects unrelated to covalent modifications of engineered cysteines. These problems are discussed in more detail by Egan et al. (1998). Regardless, the present experiments indicate that gating is not required to expose at least some residues in TMD1 to MTSEA.

\section{His33 is not responsible for the transient potentiation of wild-type $\mathrm{P}_{2} \mathrm{X}_{2}$ by $\mathrm{Ag}^{+}$}

Silver causes a long-lasting potentiation of ATP-gated current through mutant $\mathrm{H} 33 \mathrm{C}-\mathrm{P} 2 \mathrm{X}_{2}$ receptors that is the result of a leftward shift in the ATP concentration-response curve (Fig. 6). We wondered whether the transient potentiation of the WT receptor, like the longer-lasting transient potentiation of the $\mathrm{H} 33 \mathrm{C}$ mutant, also involved a shift in ATP responsiveness and whether this shift was the result of a transient modification of the 
before $1 \mathrm{mM}$ MTSEA after $1 \mathrm{mM}$ MTSEA

a.

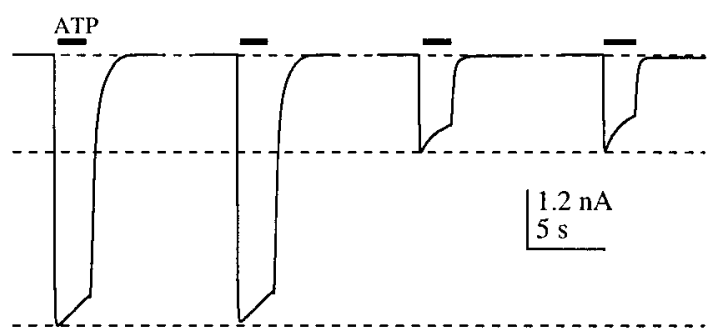

b.
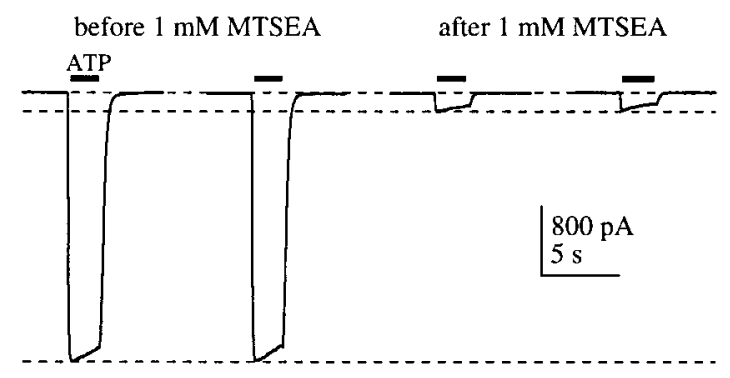

c.

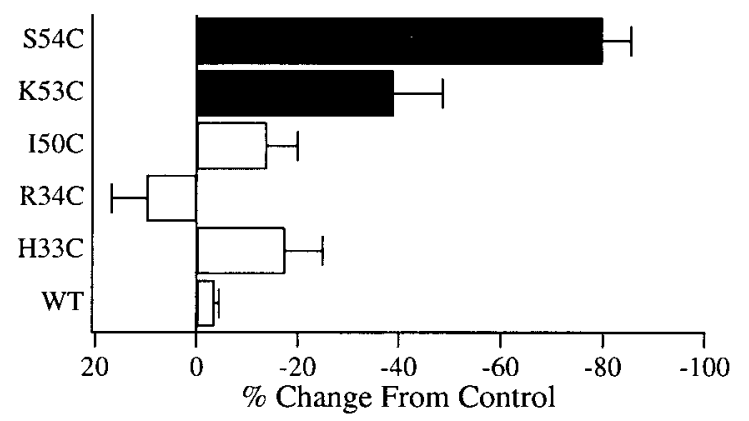

Figure 7. Sustained effects of MTSEA on H33C, R34C, I50C, K53C, and S54C. ATP-gated current was measured before and after a 5 min application of $1 \mathrm{~mm}$ MTSEA. $a, b$, Each row shows two consecutive and representative ATP-gated currents before (2 leftmost currents in each row) and after (2 rightmost currents in each row) a 5 min application of $1 \mathrm{~mm}$ MTSEA to HEK293 cells transiently expressing either K53C ( $a$ ) or S54C (b) mutant receptors. Holding voltage was $-40 \mathrm{mV}$. $c$, Average data for the effect of MTSEA on WT and the five cysteine-substituted mutants that react with $\mathrm{Ag}^{+}$when the channel is gating. Each data point is the average of three to nine individual experiments. Results significantly different $(p<0.01)$ from WT are marked with solid bars.

endogenous $\mathrm{H} 33$ of the WT receptor. To test the first part of this hypothesis, ATP concentration-response curves were generated before and during application of $500 \mathrm{~nm} \mathrm{Ag}^{+}$. Again, as expected, ATP was more potent in the presence of $\mathrm{Ag}^{+}$than in its absence (Fig. $8 a, b$ ), and this shift was accompanied by a significant change in the $\mathrm{EC}_{50}$ (before $\mathrm{Ag}^{+}, 15 \pm 2 \mu \mathrm{M}, n=19$; during $\mathrm{Ag}^{+}, 3 \pm 11$ $\mu \mathrm{M}, n=10)$. The leftward shift in the ATP concentrationresponse curve during the transient $\mathrm{Ag}^{+}$potentiation is reminiscent of the transient effect of acidification on the ATP response of recombinant $\mathrm{P} 2 \mathrm{X}_{2}$ receptors (King et al., 1996; Stoop et al., 1997) and the effect of $\mathrm{Cu}^{2+}$ and $\mathrm{Zn}^{2+}$ native receptors of mammalian neurons (Li et al., 1993, 1996a,b). To test the hypothesis that the transient potentiation of WT receptor by $\mathrm{Ag}^{+}$occurs at $\mathrm{H} 33$, we mutated this residue to leucine. ATP-gated currents through the H33L mutant were indistinguishable from the WT receptor, as was the transient effect of $\mathrm{Ag}^{+}$(Fig. $8 c$ ), indicating that the transient potentiation does not depend on the presence of $\mathrm{H} 33$.
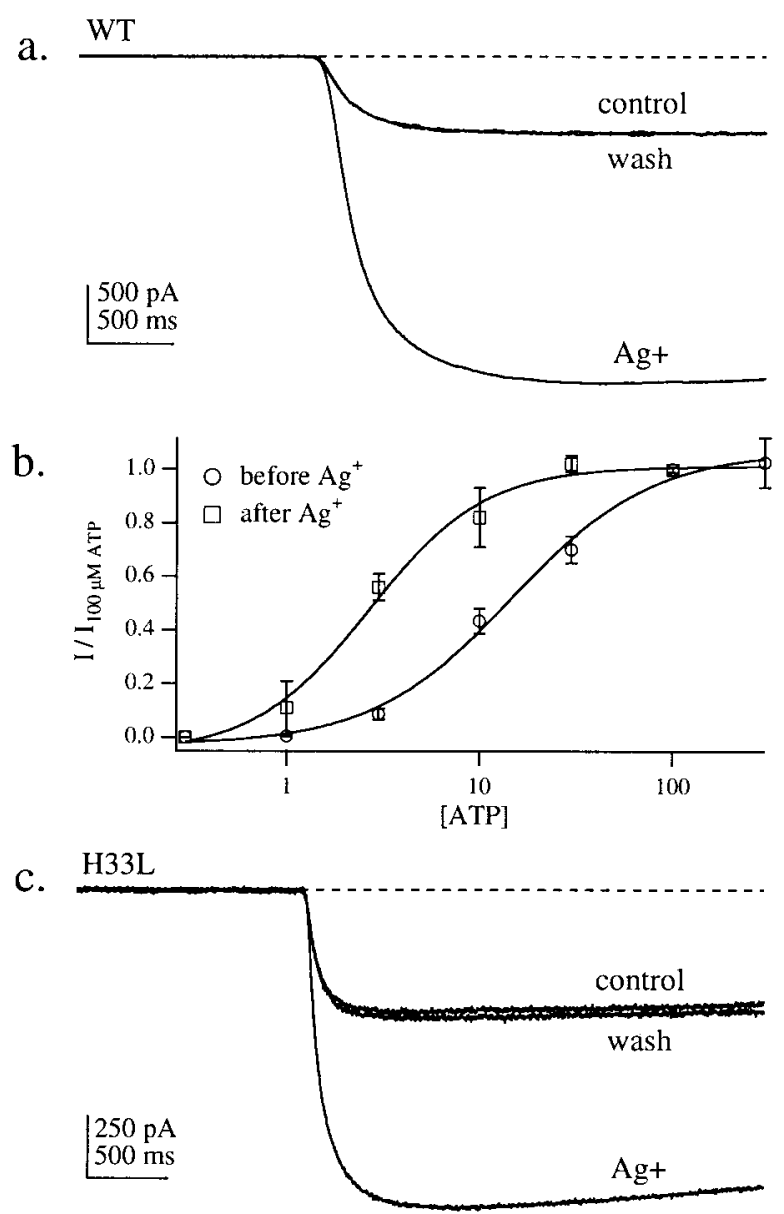

Figure 8. Transient effects of $\mathrm{Ag}^{+}$on wild-type P2X 2 and H33L. $a$, Raw data of the transient potentiation of ATP-gated current through the WT receptor of a clonal cell line by $500 \mathrm{nM} \mathrm{Ag}^{+}$. Current traces recorded before, during, and after applications of $\mathrm{Ag}^{+}$are shown for comparison. ATP was applied at a concentration of $10 \mu \mathrm{M}$. Holding voltage was -40 $\mathrm{mV} . b$, ATP concentration-response curves determined before and during application of $500 \mathrm{nM} \mathrm{Ag}^{+}$to a stable HEK239 cell line expressing WT receptor. $c$, ATP-gated current through the H33L mutant is potentiated by concurrent application of $500 \mathrm{nM} \mathrm{Ag}^{+}$. Same conditions as in $a$.

Likewise, both acidification ( $\mathrm{pH}$ 6.0) and $\mathrm{Zn}^{2+}$ potentiated ATPgated current in cells expressing H33L (data not shown), suggesting that $\mathrm{H} 33$ is not critical for these effects to occur.

\section{DISCUSSION}

We used scanning cysteine mutagenesis to identify residues in and around TMD1 that react covalently with sulfhydryl-specific reagents. This method assumes that the reagents react only with sulfhydryls exposed to aqueous environments and that modifications of hydrated residues within the water-filled channel pore sometimes lead to a change in current (Karlin and Akabas, 1998). It does not explicitly demonstrate that a residue lines the pore, and the possibility that the current changes as the result of modification of nonpore-forming residues cannot be ignored. We measured covalent modification of accessible residues by recording whole-cell current before and after applications of sulfhydrylspecific reagents; this current is equal to the product of the number of functional channels $(n)$ times the single-channel conductance $(i)$ times the probability that the channel is open $\left(P_{\mathrm{o}}\right)$. ATP concentration-response curves were constructed before and after applications of $\mathrm{Ag}^{+}$to determine whether the decreases in 
current resulted from changes in agonist potency; we saw no such changes. Specifically, although cysteine substitutions at some residues within TMD1 themselves change agonist potency, covalent modifications of these cysteines do not change potency further. This lack of effect on agonist potency suggests either of the following: (1) $P_{\mathrm{o}}$ is unchanged after modification of exposed thiolates, and the change in current results from a change in $n$ or $i$; or (2) $P_{\mathrm{o}}$ approaches zero for some but not all receptors, an option that is functionally equivalent to a change in $n$. If $n$ decreases during drug exposure, then we would expect that repeated applications of sulfhydryls-reactive reagents would eventually lead to a complete loss of the response to ATP. We did not find this to be true. Instead, repeated applications of $\mathrm{Ag}^{+}$or MTSEA lead to a steady-state inhibition that was less than complete (data not shown). Thus, although these receptors may play a role in gating (see below), the apparent explanation for the change in current amplitude that we measured here remains a change in $i$. The most likely target underlying such a change would be expected to occupy a site within the pore.

Although $\mathrm{Ag}^{+}$may reduce current by altering $i$, our data do not necessarily support a role for susceptible residues of the wild-type receptor in ionic permeability. Indeed, the relative positions of the most accessible residues near the inner and outer mouths of the channel make it unlikely that these amino acids contribute to ion selection. Rings of negative charge have been shown to promote conduction through other types of ligand-gated ion channels by concentrating cations and repelling anions in the vicinity of the pore (Unwin, 1993). Then, by analogy, the positioning of positive charge supplied by H33 and R34 at the outer limits of the cation-selective pore of the $\mathrm{P} 2 \mathrm{X}_{2}$ receptor is counterintuitive, suggesting that they are not involved in selectivity. Likewise, intrinsic rectification is a voltage-dependent property of the $\mathrm{P} 2 \mathrm{X}_{2}$ receptor that requires a charged voltage sensor to sit within the transmembrane electric field, and it is possible that the basic side chains of H33, R34, and K53 provide this charge. Again, our data show that these residues are at the extremes of the channel and are not well situated to sample the electric field. In support of this hypothesis, preliminary data suggest that neutralization of R34 does not change the slope of the currentvoltage curve and therefore is not a voltage sensor for rectification of homomeric $\mathrm{P}_{2} \mathrm{X}_{2}$ receptors (Zhou and Hume, 1998). It is worth noting, however, that currents through a number of residues in the middle of TMD1 also were reduced by application of $\mathrm{Ag}^{+}$(Fig. 5). Although these reductions did not meet the $1 \%$ confidence level that we used to judge accessibility, it is possible that some of these residues would pass a less stringent measure of significance and may therefore be active players in control of ionic conduction through the pore. Additional experiments are needed to test this hypothesis.

Some of our data do suggest a role for TMD1 in gating. First, ATP is less potent at three TMD1 mutants (H33C, R34C, and $\mathrm{K} 53 \mathrm{C}$ ) than at the WT receptor. Second, $\mathrm{Ag}^{+}$causes a temporary but long-lasting potentiation of ATP-gated current through H33C that is the result of an increase in agonist potency. A change in potency could reflect altered binding of ATP to an extracellular binding site. That $\mathrm{Ag}^{+}$changes ion conduction by directly modifying the ligand binding site seems unlikely because the mutations detailed in this study occur in a part of the protein that lies in or near the membrane (Brake et al., 1994; Newbolt et al., 1998; Torres et al., 1998). However, we cannot rule out the possibility that modification of an amino acid in the wall of the pore indirectly alters agonist binding because such changes do occur in other receptors (Wang et al., 1997). If we assume that the effect of $\mathrm{Ag}^{+}$occur downstream of the binding site, then the change in agonist potency probably reflects a change in gating kinetics. We favor the hypothesis that TMD1 and TMD2 interact as suggested by a recent study that showed that the rate of desensitization of chimeric proteins of the rapidly desensitizing $\mathrm{P} 2 \mathrm{X}_{1}$ receptor and the slowly desensitizing $\mathrm{P} 2 \mathrm{X}_{2}$ receptor depends in part on the origin of the donated transmembrane domains (Werner et al., 1996). Specifically, complete substitution of both transmembrane domains of the $\mathrm{P} 2 \mathrm{X}_{1}$ receptor into the $\mathrm{P} 2 \mathrm{X}_{2}$ receptor backbone was required to gain desensitization in a chimeric protein. Furthermore, substitution of either one of the transmembrane domains of the $\mathrm{P} 2 \mathrm{X}_{2}$ isoform into $\mathrm{P} 2 \mathrm{X}_{1}$ backbone resulted in loss of rapid desensitization. Together, the results suggest but do not prove that a significant interaction occurs between the TMD1 and TMD2 as the channel gates and that this interaction occurs at the level of the ion channel pore. In support of this hypothesis, we find that both TMD1 (this study) and TMD2 (Egan et al., 1998) line the channel pore and therefore are in close enough proximity to allow an interaction to occur.

Finally, an interaction of separate domains in the control of gating is also suggested by the prolonged potentiation of $\mathrm{H} 33 \mathrm{C}$ by $\mathrm{Ag}^{+}$that resulted from a temporary change in agonist potency. If we assume again that the effect of $\mathrm{Ag}^{+}$originates downstream of the binding site, then the change in potency reflects a change in gating kinetics. However, H33 does not seem to be solely responsible for the transient potentiation of ATP-gated current through the WT receptor by $\mathrm{Ag}^{+}$because substitution of leucine at this position did not abolish the effect. This suggests the possibility that the potentiation by $\mathrm{Ag}^{+}$results from the coordinated effort of several different protein domains and that mutation of any one domain may alter the response but not necessarily eliminate it.

In conclusion, our data demonstrate for the first time that TMD1 plays an active role in conduction through the pore of ionotropic purinergic receptors and may constitute a part of the ion channel pore. However, although it is clear that this domain influences whole-cell current, perhaps by an effect on channel gating, the data do not necessarily prove that TMD1 lines the pore. A recent study suggests that it is possible to obtain meaningful data from a single-channel analysis of homomeric $\mathrm{P}_{2} \mathrm{X}_{2}$ receptors expressed in a stable cell line (Ding and Sachs, 1999). Application of this technique to the cysteine-substituted mutants described here may help to resolve the role TMD1 plays in ion conduction.

\section{REFERENCES}

Akabas MH, Stauffer DA, Xu M, Karlin A (1992) Acetylcholine receptor channel structure probed in cysteine-substitution mutants. Science 258:307-310.

Alberts B, Bray D, Johnson A, Raff M, Roberts K, Walter P (1998) Essential cell biology, p 96. New York: Garland.

Ausubel FM, Brent R, Kingston RE, Moore DD, Siedman JG, Smith JA, Stuhl K (1995) Mutagenesis of cloned DNA, Chap 8. In: Current protocols in molecular biology (Janseen J, ed). New York: Wiley.

Brake AJ, Julius D (1996) Signaling by extracellular nucleotides. Annu Rev Cell Dev Biol 12:519-541.

Brake AJ, Wagenbach MJ, Julius D (1994) New structural motif for ligand-gated ion channels defined by an ionotropic ATP receptor. Nature 371:519-523.

Dance IG (1986) The structural chemistry of metal thiolate complexes. Polyhedron 5:1037-1104.

Ding S, Sachs F (1999) Single channel properties of $\mathrm{P} 2 \mathrm{X}_{2}$ purinoceptors. J Gen Physiol 113:695-720.

Egan TM, Haines WR, Voigt MM (1998) A domain contributing to the ion channel of ATP-gated P2X2 receptors identified by the substituted cysteine accessibility method. J Neurosci 18:2350-2359.

Holmgren M, Liu Y, Xu Y, Yellen G (1996) On the use of thiol- 
modifying agents to determine channel topology. Neuropharmacology 35:797-804.

Jakes KS, Abrams CK, Finkelstein A, Slatkin SL (1990) Alteration of the pH-dependent ion selectivity of the colicin E1 channel by sitedirected mutagenesis. J Biol Chem 265:6984-6991.

Jiang LH, Rassendren F, Surprenant A, North RA (2000) Identification of amino acid residues contributing to the ATP-binding site of a purinergic P2X receptor. J Biol Chem 275:34190-34196.

Karlin A, Akabas MH (1998) Substituted-cysteine accessibility method. Methods Enzymol 293:123-145.

Khakh BS, Burnstock G, Kennedy C, King BF, North RA, Seguela P, Voigt M, Humphrey PP (2001) International union of pharmacology. XXIV. Current status of the nomenclature and properties of P2X receptors and their subunits. Pharmacol Rev 53:107-118.

Kim M, Yoo OJ, Choe S (1997) Molecular assembly of the extracellular domain of P2X2, an ATP-gated ion channel. Biochem Biophys Res Comm 240:618-622.

King BF, Ziganshina LE, Pintor J, Burnstock G (1996) Full sensitivity of $\mathrm{P} 2 \mathrm{X}_{2}$ purinoceptor to ATP revealed by changing extracellular $\mathrm{pH}$. Br J Pharmacol 117:1371-1373.

Kriegler S, Sudweeks S, Yakel JL (1999) The nicotinic alpha4 receptor subunit contributes to the lining of the ion channel pore when expressed with the 5- $\mathrm{HT}_{3}$ receptor subunit. J Biol Chem 274:3934-3936.

Li C, Peoples RW, Weight FF (1993) $\mathrm{Zn}^{2+}$ potentiates excitatory action of ATP on mammalian neurons. Proc Natl Acad Sci USA 90:8264-8267.

Li C, Peoples RW, Weight FF (1996a) $\mathrm{Cu}^{2+}$ potently enhances ATPactivated current in rat nodose ganglion neurons. Neurosci Lett 219:45-48.

Li C, Peoples RW, Weight FF (1996b) Proton potentiation of ATP-gated ion channel responses to ATP and $\mathrm{Zn}^{2+}$ in rat nodose ganglion neurons. J Neurophysiol 76:3048-3058.

Lü Q, Miller C (1995) Silver as a probe of pore-forming residues in a potassium channel. Science 268:304-307.

Migita KM, Haines WR, Voigt MM, Egan TM (2001) Polar residues of
TMD2 influence ionic permeability of recombinant ATP-gated $\mathrm{P} 2 \mathrm{X} 2$ receptors. Biophys J 80:104.a.

Newbolt A, Stoop R, Virginio C, Surprenant A, North RA, Buell G, Rassendren F (1998) Membrane topology of an ATP-gated ion channel (P2X receptor). J Biol Chem 273:15177-15182.

Nicke A, Baumert HG, Rettinger J, Eichele A, Lambrecht G, Mutschler E, Schmalzing G (1998) P2X1 and P2X3 receptors form stable trimers: a novel structural motif of ligand-gated ion channels. EMBO J 17:3016-3028.

Ralevic V, Burnstock G (1998) Receptors for purines and pyrimidines. Pharmacol Rev 50:413-492.

Rassendren F, Buell G, Newbolt A, North RA, Surprenant A (1997) Identification of amino acid residues contributing to the pore of a P2X receptor. EMBO J 16:3446-3454.

Stoop R, Surprenant A, North RA (1997) Different sensitivities to $\mathrm{pH}$ of ATP-induced currents at four cloned P2X receptors. J Neurophysiol 78:1837-1840.

Sun Z-P, Akabas MH, Goulding EH, Karlin A, Siegelbaum SA (1996) Exposure of residues in the cyclic nucleotide-gated channel pore: $\mathrm{P}$ region structure and function in gating. Neuron 16:141-149.

Torres GE, Egan TM, Voigt MM (1998) Topological analysis of the ATP-gated ionotropic P2X2 receptor subunit. FEBS Letters 425:19-23.

Torres GE, Egan TM, Voigt MM (1999) Hetero-oligomeric assembly of $\mathrm{P} 2 \mathrm{X}$ receptor subunits. Specificities exist with regard to possible partners. J Biol Chem 274:6653-6659.

Unwin N (1993) Neurotransmitter action: opening of ligand-gated ion channels. Cell 72:31-41.

Wang HL, Auerbach A, Bren N, Ohno K, Engel AG, Sine SM (1997) Mutation in the M1 domain of the acetylcholine receptor alpha subunit decreases the rate of agonist dissociation. J Gen Physiol 109:757-766.

Werner P, Seward EP, Buell GN, North RA (1996) Domains of P2X receptors involved in desensitization. Proc Natl Acad Sci USA 93:15485-15490.

Zhou Z, Hume RI (1998) Molecular determinants of voltage-dependent gating of $\mathrm{P} 2 \mathrm{X}_{2}$ receptor currents. Soc Neurosci Abstr 24:2028. 